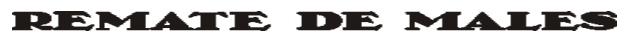

Campinas-SP, v.38, n.2, pp. 853-884, jul./dez. 2018

\title{
ÍTACA AO REVÉS
}

\section{Henrique Estrada Rodrigues ${ }^{1}$}

\author{
Para Marcelo Jasmin, \\ que conhece muitas Ítacas.
}

Resumo: O artigo analisa o poema Finismundo: a última viagem, publicado por Haroldo de Campos em 1990. Este texto trabalha com a hipótese de que Finismundo, embora construído do ponto de vista do naufrágio das utopias (do naufrágio de certo "aventuroso deslugar", segundo termos do poema), ainda pontua uma hybris ironicamente utópica. Para desenvolver essa questão, a análise aqui proposta se atém ao modo como Haroldo de Campos desenvolve o tema das viagens de Odisseu a partir de sedimentos poéticos provenientes tanto do cânone literário (especialmente Homero, Dante e Pound) como de seu próprio trabalho autoral (uma vez que o herói grego e o tema da viagem são topoi constitutivos da obra poética, tradutória e ensaística que precede Finismundo).

Palavras-chave: Haroldo de Campos; Odisseu; Utopia.

"no lugar

da ventura o aventuroso deslugar".

(Haroldo de Campos, 1990)

1.

Em 1990, quando já passa dos 6o anos, Haroldo de Campos publica o longo poema Finismundo: a última viagem, no qual retoma e reinterpreta a mítica personagem de Odisseu. Publicado em edição artesanal, a cargo do poeta e tipógrafo Guilherme Mansur, reeditado em 1996 pela Sette Letras e reinserido no interior do livro Crisantempo, de 1998, o poema é a

1 Departamento de História da Pontifícia Universidade Católica - PUC-Rio: $<$ henriqueestrada@hotmail.com>. 
singular peça de uma elaboração poética em torno da múltipla identidade da personagem heroica. Essa elaboração, lembra o próprio autor (1996, p. 16) em depoimento sobre a gênese de Finismundo, foi dividida em duas partes. A primeira, com tonalidade épica, é atravessada pelas sombras de Homero. Mas ao poeta brasileiro não interessava apenas aquela personagem que, na Odisseia, após dez anos na guerra de Troia e outros dez na longa viagem de retorno ao lar, reencontra a Ítaca natal e reassume seus direitos de senhor sobre a casa aristocrática. Interessava-lhe o "mais além”, instigado tanto pela predição de Tirésias sobre os últimos dias do herói, ouvida pelo próprio Odisseu em sua descida ao reino dos mortos (canto XI da Odisseia), como pela Comédia de Dante (canto XXVI do "Inferno"), quando o poeta toscano expõe a última audácia - a última hybris - da personagem lendária: abandonar, já velho, a família e os deuses do lar em busca de novas experiências, numa empresa marítima que será punida com o naufrágio. Já a segunda parte de Finismundo redescreve o herói, agora urbano e sem grandes feitos a realizar, transitando em um mundo cotidiano destituído de transcendência. Sua tonalidade é irônica e romanesca, como se a prosa do mundo cotidiano - do Ulysses de James Joyce, por exemplo - desse o tom dos versos entrecortados da última parte do poema.

Nesse sentido, vale para as quatro ou cinco páginas de Finismundo aquilo que Piero Boitani (2005a), em outro contexto, dissera sobre os Cantos de Ezra Pound, obra queo poeta brasileiro, ao ladodo irmão Augusto de Campos e do amigo Décio Pignatari, parcialmente traduziu no final dos anos 1950 e início de 1960: Haroldo de Campos opera a retomada de uma personagem homérica "por meio de versões e reproduções de épocas sucessivas, como aglutinação de sedimentos poéticos, como sombra literária - a sombra de uma sombra - que o canto XI da Odisseia projeta no tempo" (BOITANI, 2005a, p. 6). Mas talvez isso ainda não seja tudo. Pois as viagens de Odisseu em Finismundo parecem se converter em sombra da própria poética haroldiana, ao menos de seu permanente confronto com os impasses da criação literária, entre o fim do ciclo da vanguarda concretista (que protagonizara nos anos 1950 e 1960) até a procura por novas dicções poéticas. De fato, se levados em conta as palavras do autor do poema, seus versos também teriam uma dimensão metalinguística, como se Finismundo falasse, metaforicamente, sobre a própria aventura pela linguagem: 


\begin{abstract}
Então, no final do ano passado - diz Haroldo em depoimento publicado em 1991 - que foi quando comecei a escrever Finismundo, eu estava fazendo um balanço desses 40 anos de produção poética. E o problema que aqui se colocava, àquela altura, que de resto, se tem colocado através de toda minha carreira poética, é aquele que está quase na raiz do meu trabalho: o enfrentamento constante que o poeta acaba tendo com o fazer poético. [...] Como fazer? Por que fazer? Até onde é possível fazer o novo, na medida em que a poesia envolve uma prática e uma história. [...] e o poeta que tinha 19 para 20 anos nos anos 50, tem agora 61 nos anos 90 - isso se coloca cada vez mais fausticamente, quer dizer, há uma constante tentativa de recuperar aquele pique inicial e se colocar novamente diante da questão do enfrentamento com a dificuldade de fazer o novo. (CAMPOS, 1996, pp. 13-15)
\end{abstract}

Finismundo, assim, articula a aventura da criação literária ao tema das viagens de Odisseu. Para isso, também elabora uma especial articulação entre envelhecimento (o de Odisseu em Ítaca, o do próprio poeta e o do seu antigo pathos concretista) e "revivescência" (a capacidade de perfazer, transformando, a antiga força ativa e criativa). Além disso, por intermédio de sedimentos poéticos de diversas procedências (temáticas e metalinguísticas), repensa os próprios impasses e potencialidades da curiosidade em sua aspiração à aventura e à versatilidade. De resto, para um poeta que chegou a nomear o poema de 1990 como "pós-utópico", vale dizer, como uma obra elaborada a contrapelo tanto dos projetos coletivos de vanguarda como das viagens utópicas ancoradas no futuro, repensar a revivescência num horizonte de expectativas rebaixadas não parecia pouca coisa. E não foi pouco, sobretudo, uma perspectiva crítica e poética que, antes de fazer do "pós-utópico" o réquiem das utopias, buscou repensar as potencialidades da utopia negada. Essa, ao menos, é a questão geral que orienta este texto: a singular dialética entre fim e começo em Finismundo não poderia ser lida como um modo de repensar, poeticamente, as condições de revivescência da própria utopia tantas vezes negada?

Certamente, não foi nesse poema que Haroldo de Campos abordou essa singular dialética pela primeira vez. Nos anos 1980, seja no poema "Opúsculo goetheano" (do livro A educação dos cinco sentidos, de 1985), seja em ensaios sobre Goethe (posteriormente reunidos em $O$ arco íris branco, de 1997, ou mesmo antes, em Deus e o Diabo no Fausto de Goethe, de 1981), ele já teria nomeado a capacidade de "revivescência" como "enteléquia": "a força que nos conduz ao telos, à completude" (GOETHE apud CAMPOS, 1997, p. 20), força que compele a natureza - continua Campos, parafraseando o autor alemão - a atribuir aos seres novas formas de existência quando a forma antiga transforma-se em obstáculo à força 
de criar e existir. De fato, nessa quadra de sua obra, ele se aproximara do modo goetheano de representar o dinamismo da natureza e sua força de intensificação da vida. E, assim o fazendo, não deixa de insinuar uma possível confluência entre enteléquia e utopia. ${ }^{2}$

Se Finismundo, por sua vez, comporta algo de singular, talvez o seja por sugerir, agora, uma aproximação entre a enteléquia e a hybris ambígua e irônica de Odisseu, por intermédio da qual repensa o "risco da criação como um problema de viagem” (CAMPOS, 1996, p. 15). Essa aproximação não constituiria um modo específico de se contrapor à aceitação conformista e antiutópica da prosa do mundo cotidiano? Haroldo de Campos também não parece, nesse contraponto, desenhar a utopia não como conteúdo para uma consciência, mas como um logos (linguagem e forma de pensamento) viajante e imaginativo, como uma lógica poética que jogaria seus dados com a transgressão dos limites? Sob as sombras de Odisseu e das utopias, cabe-nos enfrentar essas duas questões.

\section{2.}

O livro fundador do imaginário utópico, a Utopia de Thomas More, já se inscrevera sob o selo da viagem e da transgressão dos limites. Fora um navegante luso que descobrira, nos arredores do Novo Mundo, Outro Mundo; um marinheiro saído das hostes das navegações não de qualquer viajante, mas de um Américo Vespúcio siderado pela Comédia de Dante e pelo Ulisses do canto XXVI do "Inferno", a ponto de modelar sua persona sob o selo da última hybris do herói dantesco. Vespúcio, lembra Boitani (2005a, p. 40), amava "ver a si mesmo como um Ulisses e um Dante, e ler as próprias viagens à luz daquelas da Comédia". More, por sua vez, achou por bem modelar sua viagem ficcional a Outro mundo como um problema de enfrentamento com o desconhecido. Mais ainda, temperou a ânima do descobridor da ilha da Utopia - o português Rafael Hitlodeu - com a astúcia do Odisseu homérico, com a curiosidade desmedida do Ulisses dantesco e também com a verve de Platão, embora parecesse aludir, aqui, não apenas ao autor da República, mas também àquele suposto viajante pelo Mediterrâneo que, em Siracusa, pretendera educar o seu tirano, como relatado na chamada Carta VII, de autoria não totalmente definida, embora muitos pensem ser da lavra do próprio Platão ou de seu círculo.

2 Remeto o leitor, nesse ponto, a um artigo em que desenvolvi a confluência aqui assinalada (RODRIGUES, 2017). 
Entre Platão, Homero e Dante, interessava a More (1993, p. 13) imaginar o navegante português atravessado por algo parecido com o que se pode chamar de a "aura" do viajante:

\begin{abstract}
A julgar por sua pele e seus trajes [diz More], imaginei tratar-se [Hitlodeu] de um marinheiro. [...] Depois de conhecê-lo [responde Peter Giles, nesse diálogo que abre o $1^{\circ}$ livro da Utopia], gostareis dele por suas próprias qualidades, pois não existe no mundo outro homem capaz de contar, como ele, tantas histórias a respeito de terras estranhas e seus habitantes. ${ }^{3}$
\end{abstract}

Walter Benjamin (1987, p. 199) chamaria essa capacidade aurática do contador como o "saber das terras distantes". "Distância", de resto, é um termo bastante presente na topologia dos contadores e dos viajantes; e também na das utopias, ao menos se se compreender o termo não apenas num sentido mensurável (espacial ou temporalmente), mas também - e sobretudo - como aquela espécie de "distância absoluta" [l'écart absolu] de que falava Charles Fourier (1846). Com essa designação, Fourier enunciava um modo humanamente utópico de figurar, na aventura pelo mundo, as inquirições do real: "A distância absoluta. Eu presumo que o melhor meio de chegar a descobertas úteis é se afastar, em todos os sentidos, das rotas seguidas pelas ciências incertas" (p. 4). Talvez assim, continua, se possa abordar problemas ainda não discutidos e evitar os interesses do trono (inovações administrativas) e do altar (inovações religiosas). Nenhuma relação com a administração e o sacerdócio, reitera Fourier (pp. 4-5).

Haroldo de Campos também foi exímio viajante, com uma vida marcada por deslocamentos sucessivos e pelo elogio à aventura por diferentes geografias e linguagens. Do elogio à elegia foi um passo. Sua obra poética é mesmo marcada por recorrentes odes à viagem, trabalhada ora como matéria para o poema, ora como forma poética de inquirir a existência. Se o póstumo Entremilênios (publicado em 2009) chegou a criar uma seção inteira para abrigar esses dois lados de uma mesma moeda (chamado "circum-stâncias", essa seção contém poemas como "visão em veneza", "visitando a domus aurea", "milano revisitado: 2001”), Crisantempo (de 1998), que o antecedeu em onze anos, é um livro atravessado por poemas que figuram a viagem como modalidade de implicação do homem no mundo e na história. Não por acaso, Finismundo, reinserido nessa publicação, foi inicialmente pensado como

3 Sobre os aspectos formais do livro de More, conferir a edição crítica preparada por Prévost (1978). Ver também, a este respeito, Abensour (1990) e Ginzburg (2004). 
um possível nome para essa coletânea. E se é fato que a feição ambígua e problemática de Odisseu foi vetor central desse poema específico, também é verdade que o motivo da viagem, enquanto polo aglutinador de múltiplas referências e temporalidades, também atraíra para o interior de Finismundo sedimentos poéticos oriundos da obra precedente de Haroldo de Campos. O viajante Odisseu, particularmente, é um verdadeiro topos - enquanto imagem pletora de motivos, sentidos e tradições intelectuais - de sua trajetória intelectual.

O confronto de Haroldo de Campos com essa personagem ganha corpo nos anos 1960 quando traduz o Canto 1 dos Cantares de Pound ele próprio uma tradução para o inglês de uma tradução latina do trecho grego da Odisseia (canto XI), em que o herói desce ao reino dos mortos. ${ }^{4}$ Também nos anos 1960 o poeta dá início a Galáxias, obra concluída na segunda metade da década de 1970 e só publicada integralmente em 1984. Odisseu, personagem presente em alguns dos cinquenta cantos desse livro, é parte de um gesto épico que, nos termos do seu autor (CAMPOS, 1984, [s.p.]), "vive sob a espécie da viagem”. O próprio poeta sugeriu (CAMPOS, 1991), e mais de um comentador analisou (BOITANI, 2005b; JACKSON, 2005) que Finismundo opera, num recorte ambíguo e condensado, o modo de Galáxias figurar o narrador como uma espécie de Ulisses barroco, viajando por diferentes geografias, línguas e mitos.

Viagem barroca também presente, de maneira igualmente mais concentrada que em Galáxias, no livro Signantia quase coelum, Signância quase céu (de 1979), que retrabalha o motivo central da Comédia - a peregrinação por estratos do inferno, purgatório e paraíso - numa sintaxe entrecortante (pouco narrativa e com disposição plástica e visual das palavras) muito próxima dos procedimentos concretistas. Nesse livro, a declinação do título - "Signantia", o particípio presente e plural do verbo latino signo (marcar, caracterizar, gravar, traçar, assinalar) - sugere uma viagem por signos literários de diversas procedências, entre as quais a sombria nekuia (a invocação dos mortos para a previsão do futuro) e a

\footnotetext{
4 O livro Cantares de Ezra Pound (com Augusto de Campos e Décio Pignatari), no qual se encontra o $1^{\circ}$ Canto, foi publicado em 1960. Revisto e ampliado, reaparece em 1983 em: Pound (1983), com Augusto de Campos, Décio Pignatari, José Lino Grunewald e Mário Faustino.
} 
assombrosa hybris (a orgulhosa transgressão dos limites). Grafados no livro em negrito ou em letras expandidas, esses são signos que, assinalando episódios ou traços de caráter de Odisseu, terminariam marcando boa parte da obra haroldiana.

De fato, essa marca se expandiria por outras tantas produções da sua lavra poética, crítica e tradutória. No registro da criação literária - em que se inclui, para Haroldo de Campos, a tradução -, Odisseu se fará presente em muitos momentos, especialmente em suas versões da Ilíada (integral) e da Odisseia (poucos trechos, como a nekuia no canto 11 ou o episódio sobre o "melicanoro cantar" das sereias, do canto 12). Ainda no terreno tradutório, Ulisses é retomado a partir da tradução de poemas de diferentes línguas, como o "Ulisses" de Tennyson ou "A última viagem" de Giovanni Pascoli. ${ }^{5}$ Paralelamente às traduções de antigos e modernos, Haroldo de Campos também repensou a fisionomia do herói por intermédio da criação autoral, a exemplo de dois poemas sobre o múltiplo caráter da personagem, publicados no póstumo Entremilênios (2009): "Lendo a Ilíada 2" e "Lendo a Ilíada 10". O primeiro deles se destaca. Em feição lírica e sob o fascínio dos epítetos e designações de Odisseu (multimanhoso; multimaligno; multiglorioso; inclemente; luciferino nauta; multilabioso; Nãodisseu Nenhum-Homem), o poeta incorpora, como em Finismundo, resíduos literários de diversas épocas e autores para inquirir o ethos (o caráter e o sentido das iniciativas) do rei de Ítaca:

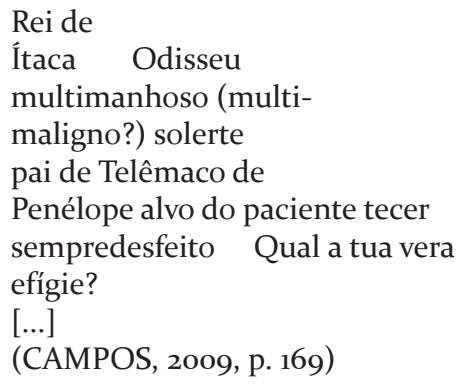

Por sua vez, no registro da pesquisa e da interpretação crítica, alguns momentos foram decisivos em seu confronto com esse topos literário, com

\footnotetext{
5 Os trechos da Odisseia (a nekuia e o "canto das sereias"), bem como os poemas de Tennyson e Pascoli (além de outros poemas sobre "Ulisses"), foram reunidos em apêndice ao já citado livro de Piero Boitani (2005a). A este respeito, ver também, de Haroldo de Campos, o capítulo "Terceiras transluminuras", do livro Entremilênios, no qual também se pode ler razoável conjunto de traduções em que Ulisses é personagem central.
} 
implicações no seu modo de trabalhá-lo poeticamente. Sabe-se, através de depoimentos do próprio Haroldo de Campos, o quanto ele teria aguçado o olhar para a personagem a partir da leitura de um texto de D'Arco Silvio Avalle intitulado "L'ultimo viagio d'Ulisse", capítulo do livro Modelli semiologici nella Commedia di Dante (1975). A consulta ao exemplar que pertenceu a Haroldo de Campos, hoje depositado na fundação Casa das Rosas, em São Paulo, permite que se perceba, nos recorrentes grifos e na ampla marginália produzida, um léxico que, posteriormente, seria retrabalhado nos próprios versos de Finismundo - a hybris, o naufrágio, a viagem, as razões de Ulisses, para citar apenas alguns subscritos presentes nas margens do livro de Avalle que a ele pertencera. Por fim, não há como esquecer: Ulisses também foi objeto de comentários esparsos (a exemplo do depoimento sobre a gênese de Finismundo, publicado na reedição de 1996 do poema) e entrevistas (como a dada a Gerald Thomas em 2002, disponível o Youtube), onde se percebe o fascínio haroldiano pela ambiguidade de uma personagem cujos disfarces e jogos de linguagem levavam aqueles que se lhe antepunham ora à salvação, ora à perdição.

Por tudo isso, vale a pena investigar, com mais cautela, os principais lances desse sedimento literário, crítico e tradutório na obra haroldiana. Cabe analisar, especialmente, a inscrição de Odisseu, enquanto topos poético, na obra literária que precede Finismundo, ao menos em dois momentos: o primeiro, dedicado à tradução haroldiana do $1^{\circ}$ Canto de The Cantos de Ezra Pound, publicada em 1960; o segundo, focado em Signantia quase coelum (1979) e na prosa poética de Galáxias (1984). Talvez esse seja um bom caminho para se compreender o modo como Finismundo, entre a nekuia e a hybris, catalisaria toda uma atmosfera heroica para relançá-la rumo a certo "aventuroso deslugar".

O primeiro encontro crítico e poético de Haroldo de Campos com Odisseu - ao menos, o primeiro com consequência decisiva para sua estruturação enquanto topos poético - ocorre no final dos anos de 1950, quando participa, com Augusto de Campos e Décio Pignattari, da tradução parcial do longo poema épico The Cantos, de Ezra Pound (1983). Esse poema pode ser lido como um singular passeio pelas ruínas e promessas da história mundial, iniciado com a inclusão de um pequeno trecho da Odisseia, já na sua abertura. Trata-se, mais especificamente, da inclusão de certo episódio do canto 11, aquele em que Homero narra a 
descida de Odisseu ao reino dos mortos, a chamada Nékuia, quando o rei de Îtaca encontra as sombras do insepulto amigo Elpenor, de sua mãe e, logo depois, do profeta Tirésias. Pound recupera esse episódio e o insere, numa tradução própria, como o Canto 1 do seu livro, interrompendo sua citação pouco antes de Odisseu ouvir as predições do velho Tirésias sobre os últimos dias do herói, ou seja, pouco antes da passagem (central para o poema "Finismundo", como se verá mais adiante) em que se prediz, ambiguamente, a morte do herói ex halos - ex podendo indicar tanto "fora do" como "proveniente do" mar (halos). E o poeta americano ainda conclui seu curioso trabalho poético e tradutório, sinalizando, no final do Canto, a fonte usada: a tradução latina de Homero realizada por Andreas Divus em 1538, agora vertida do latim para o inglês com traços rítmicos e aliterativos próximos do inglês arcaico do poema The Seafarer. ${ }^{6}$

Ao que se sabe, é em 1915 que Pound começa a escrever os primeiros versos de The Cantos, esse longo poema com História, segundo a conhecida definição poundiana para poema épico. Poucos anos depois, trava contato com James Joyce, cujo Ulysses, publicado em 1922, o fascinaria por sua articulação entre intriga realista, multiplicidade caótica da vida moderna e evocação, no presente, de vozes passadas (READ, 1966, pp. 491-496). A partir de 1923, Pound reordena o material em curso para dar lugar privilegiado à nekyia, à descida de Odisseu aos infernos. Finalmente, com esse episódio termina por abrir The Cantos em sua primeira edição, publicada em 1930 (a obra continuaria a ser acrescida de novos cantos ao longo de toda sua vida). Sob a estampa da nekyia o livro realiza, pois, um gigantesco périplo através de uma pluralidade de vozes e tradições, como se Pound elaborasse seu poema sob a efígie daquele herói que, já no início da Odisseia, anunciara seu fado: "Eu conheci os costumes de muitos homens e vi muitas cidades" (HOMERO, 2011, p. 25), dissera em passagem muito apreciada pelo poeta americano. Talvez seja essa passagem, de resto, uma boa epígrafe para o lugar da persona de Odisseu em The Cantos.

6 Hugh Kenner lembra, em seu livro The Pound Era (1971, p. 349), que esse 1o Canto articulara quatro "inícios": o mais antigo inglês (os ritmos e a dicção do Seafarer), a antiga Grécia (a nekyia), as origens do Renascimento (o que reafirma o frescor de Homero) e os procedimentos das vanguardas do início do século XX (como o chamado "Vortex", que tivera no próprio Pound um de seus protagonistas). Por outro lado, sobre o modo haroldiano de se apropriar de Pound, ver ensaio de Dirceu Villa (2010, p. 43), cuja nota de rodapé 11 sugere que, além de Kenner, outro bom livro para acompanhar a leitura de The Cantos seria o Companion to The Cantos of Ezra Pound, organizado por Carrol F. Terrell. 
Pound não parecia ecoar, com sua tradução da tradução, um sentimento de nostalgia pelo passado. Para o poeta, Odisseu é uma persona literária com a qual imagina, no $1^{\circ}$ e em tantos outros cantos do livro, uma viagem heroica pelos destroços, vozes e expectativas da civilização, numa obra em progresso que, de 1930 em diante, é cada vez mais radical. Ela fascinara os irmãos Campos (Augusto de, 1989; Haroldo de, 2010) pelo manejo de inúmeras referências históricas e lendárias, pelo uso de línguas diversificadas e de verdadeiros mosaicos de citações, pela exploração de diferentes procedimentos rítmicos, sintáticos e visuais. Ao construir correspondências entre imagens ou personagens de diferentes épocas, o longo poema visava tornar presentes todas as coisas consideradas ainda vivas, carregadas de significado e, por isso mesmo, capazes de interpelar o mundo contemporâneo. Seria essa a utopia possível em meio a uma história mundial da usura ceticamente pensada, pelo poeta americano, como sem futuro? A resposta a essa questão exigiria uma leitura mais atenta do poema, o que não será feito aqui. Para este texto, cabe apenas destacar que Haroldo de Campos (2010, p. 194) reconhecera, em The Cantos, uma espécie de proto-humanismo, especialmente presente na derradeira persona de seu autor, a quem visitou em 1959:

Pergunto-lhe, já entrosado no seu ritmo particular de diálogo-monólogo: E há um plano para o término dos Cantos? - Não. Só non falsificare. Dante tinha uma ordem fixa e um mundo topografado pela teologia de São Tomás. O mundo de Confúcio era um mundo em movimento, the process. Não estou hipnotizado pelo número 10o, nem por uma forma qualquer, circular ou outra. A Europa, depois da guerra, é como os restos de um vulcão erupto: é preciso recolher os fragmentos. [...] Pound [conclui Campos], em sua derradeira persona, é um moralista confuciano, que sublimou a ideologia em utopia, e fez da ética de seu desencanto uma última "agenda": pretextos para o agir.

Assim como em texto de seu irmão (CAMPOS, 1989, p. 101), esse depoimento apenas tangencia os momentos em que Pound, em caminho inverso, também sublimou a utopia em ideologia regressiva e aristocrática, cuja deriva para uma interpelação moral da vida contemporânea, embora responsável por cenas irônicas e corrosivas dirigidas ao "homem comum", também o seria por uma hostilidade à usura eà especulação financeira que, como se sabe, levara o poeta americano a naufragar no mar de tendências políticas obscuras.7 Seu ápice ocorre nos anos 1940, na Itália, quando

7 A este respeito, bem como sobre a relação entre os concretistas e a obra de Pound, ver o texto "Aumentando a temperatura referencial: reverberações poundianas na poesia concreta brasileira", de Marjorie Perloff (2017, pp. 55-56). 
faz propaganda radiofônica favorável ao fascismo e ao antissemitismo. Esses programas o levaram, ao final da Guerra Mundial, à prisão em Pisa e, depois, à internação num manicômio judiciário nos Estados Unidos. Quando Haroldo de Campos inicia correspondência com Pound, nos anos 1950, ele ainda se encontrava internado.

Seja como for, assim como inúmeros literatos de sua geração, Augusto e Haroldo de Campos consideraram The Cantos uma obra incontornável. E em 1960, quando publicam, junto com Décio Pignatari, a versão parcial desse livro, a tradução haroldiana do “1o Canto" persegue o inventivo jogo poundiano de borrar as fronteiras entre tradução e criação literária, de pensar o ato de traduzir como uma aventura criativa pela linguagem. $\mathrm{O}$ poeta brasileiro continua tal aventura propondo uma curiosa tradução (para o português) da tradução de Pound (para o inglês) da tradução de Divus (para o latim) do texto grego. Sua parte na tradução coletiva dos Cantos contribuíra, sobretudo, para a abordagem do trabalho tradutório, enquanto risco de criação, ou melhor, como "transcriação", segundo conceito elaborado pelo poeta brasileiro - posteriormente - para seu ofício tradutório. Com essa singular "tradução da tradução da tradução", Haroldo de Campos assimila um aporte crítico e inventivo fundamental para sua obra, segundo o qual a língua (a do poema The Cantos e a dos Cantares; a língua de partida de toda tradução e a de chegada) poderia ser pensada como uma língua de "lugar-nenhum", como um "não-lugar" (ou-topos) prévio a todo nacionalismo linguístico. ${ }^{8}$

Talvez seja este o alvo da tradução (da tradução da tradução): inventar uma forma de linguagem viajante e "sem lugar" fixo, correlata à invenção de uma figura do tradutor-viajante sem nostalgia de retorno a uma Ítaca natal da linguagem. Nas palavras de Olgária Matos (2005, p. 146), esse gesto tradutório romperia o dogma da unidade do original, "pois a tradução manifesta que o caráter originário é sempre plural". Haroldo de Campos, continua Matos, iria se afastar da apreciação, como a de Benjamin, sobre uma origem das línguas, uma língua pura, não instrumental e nomeadora. Ele preferia falar, "ao que tudo indica, em um milagre da multiplicação das línguas” (p. 146). Assim, a tradução do

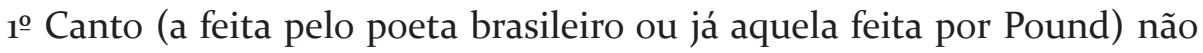
corresponderia a uma espécie de "utópica da tradução"? E não é bastante

8 Em outro contexto, analisei essa questão à luz do que chamei de "utópica da tradução" (RODRIGUES, 2015). A ideia da língua como ou-topos (um "não-lugar" prévio a todo lugar) é da lavra de Emmanuel Lévinas (2005). 
significativo o fato de que essa utópica tenha sido elaborada sob os signos da viagem e do heroísmo - uma viagem por épocas, línguas e referências poéticas de diferentes proveniências; um heroísmo elaborado num jogo de espelhos entre a figura de Odisseu e a do Poeta-tradutor?

Por tudo isso, é bem plausível que o poeta brasileiro tenha começado a pensar seriamente na persona de Odisseu a partir da leitura atenta de The Cantos, poema que atualizara as vozes do passado numa forma de linguagem inquiridora sobre a aventura humana pela história e pelos dilemas do mundo do conhecimento e da criação. Finismundo, como aqui foi anotado, também opera sob as sombras de Odisseu. Resta saber até que ponto não poderia ser abordado como uma espécie de releitura, em miniatura, da singular forma de linguagem poética explorada por Pound, que fizera da nekuia, essa viagem em direção aos mortos e detritos da civilização, o signo de uma curiosidade que oscilara entre inventividade e insensatez. $\mathrm{O}$ alcance dessa hipótese de leitura será posto à prova mais adiante, quando se adentrar na leitura de Finismundo. Por ora, ainda se considera necessário descortinar outros sedimentos poéticos que, na obra precedente de Haroldo de Campos, ajudam a compreender como um topos viajante seria utopicamente repensado no poema de 1990.

Desses sedimentos poéticos, dois têm especial relevo: Signantia quase coelum, Signância quase céu, de 1979, e Galáxias (elaborado num crescendo desde os anos 1960, publicado integralmente em 1984). Esses livros se destacam dos anteriores Auto do possesso (1950) e Xadrez de estrelas (1976) por se constituírem não como reunião de poemas esparsos, mas como obras, por assim dizer, unitárias e com coerência arquitetônica. E na arkhé de ambas se reconhece não apenas o topos fundante da viagem, mas também a sombra de um Odisseu que, entre evocações a Homero, Dante e Pound (mas não somente), se projeta nos versos dos livros quase sempre que Haroldo de Campos pensa o fazer literário sob o signo da hybris, do enfrentamento com o impossível. Isso ocorre, particularmente, no livro Signantia quase coelum, composto quase ao mesmo tempo em que traduzia poemas de Dante, especialmente cantos do "Paraíso".

Organizado em três seções, Signantia inverte o percurso ascendente, céu acima, da Comédia. Iniciando-se no "quase céu", a obra haroldiana termina - após um purgatório de ações intermediárias "sem furor sem glória/ sem pranto" (CAMPOS, 1979, p. 61) - com uma "descida aos 
infernos”. Em Homero, Odisseu desce ao Hades e termina ouvindo, de Tirésias, a previsão sobre os seus últimos dias. No canto XXVI do "Inferno", o peregrino Dante, personagem de seu próprio livro, ouve de Ulisses, condenado às chamas por suas mil astúcias e mentiras, o episódio da sua morte num naufrágio, como se a Comédia viesse cumprir - segundo a leitura de Boitani (2005a, pp. 1-13) - a profecia de Tirésias. Pound também retoma o episódio homérico sobre a nekyia em The Cantos, embora o tenha interrompido, como já visto, pouco antes dessa enunciação profética. Haroldo de Campos, por fim, parece rearticular todas essas referências, embora o faça em um poema de feição experimental e sintética, a contrapelo da monumentalidade épica de Homero, Dante e Pound.

A sintaxe entrecortante de Signantia, bem como a estruturação visual do livro - procedimentos característicos da vanguarda concreta -, permitem a leitura de seus versos e páginas em múltiplas direções. Porém, essa disposição antilinear sugere uma linha estruturante cujo compasso é dado pelo próprio léxico presente nos títulos de suas três partes: quase (signantia quasi coelum), trânsito/viajante (status viatoris: entrefiguras), esboço (esboços para uma nékuia). De fato, o leitor parece avisado de que sempre percorrerá, com o poeta, um cosmos de signos - a signância - carente de um sentido de totalização. ${ }^{9}$ Iniciando-se num "quase", o "quase céu" de sua primeira parte, um céu de palavras (ou "teofania de signos", nos dizeres do livro), a viagem inscreve um sistema de imagens de radiosa luminosidade ("azul mais claro", "raia de rubi rutilante", "escritura solar", "grifos amarelos", "o olho fosfóreo de Dante”). Na sequência, o leitor atravessa um "estado de trânsito", ou melhor, um "status viatoris: entrefiguras", pensado como um purgatório de luzes pouco cintilantes ou já extintas ("cemitério de fósforos riscados", "uma/ combustão cotidiana”). Em boa medida, trata-se de um purgatório comparável à segunda parte do poema Finismundo (que será analisada no final deste texto), poema este que retoma, em 1990, algumas imagens do livro de 1979 para descrever "um fogo prometeico" capitulado na e resumido "à cabeça de um fósforo". E a Signantia se encerra em "Esboços para uma Nékuia", que, antes mesmo de se mostrar como a queda final de toda luminosidade heroica, é representada como um "êxito ao revés", ou seja, como uma queda

9 Para uma leitura diferente, que sugere, justamente, uma "sensibilidade totalizadora" (um "respiro total”) em Signantia, ver o prefácio de João Alexandre Barbosa (1979, pp. 14-15) ao livro. 
rumo à salvação - só um esboço -, sugerida, paradoxalmente, por signos luciferinos.

Signos luciferinos e tempestuosos: Haroldo de Campos se refere a poetas que, desde os anos 1950, submetera, com seus companheiros concretistas, a intenso processo de revisão crítica, reabilitando-os seja do esquecimento (Kilkerry), seja da incompreensão de um romantismo canônico (Sousândrade, cujo "Inferno de Wall Street" chegou a comparar a The Cantos), seja ainda da resistência acadêmica à língua ferina e iconoclasta de matiz antropofágica (Oswald de Andrade). Se esses três poetas receberam, dos concretistas (especialmente dos irmãos Campos) atenção crítica e cuidadosos trabalhos de reedição de livros e textos, em Signantia seus nomes aparecem como pontos de uma constelação verbal e visual regida pela palavra Húbris, inscrita assim mesmo, em caixa alta, no livro (CAMPOS, 1979, pp. 78-79). Essa constelação abarca duas páginas seguidas que, entreabertas, formam um mesmo conjunto verbal e visual. Talvez seja a primeira vez que esta palavra, hybris, ganha tanto destaque na poesia haroldiana, mobilizada para figurar heroicamente a chamada (na esteira de Pound) poesia de invenção, feita por autores que "descobriram um novo processo ou cuja obra nos daria o primeiro exemplo conhecido de um processo" (POUND, 1961, p. 39). Trata-se, pois, de circunscrever, sob o selo da desmedida, poetas que teriam escrito contra o seu tempo.

Assim, a nekyia haroldiana, paradoxalmente, contém algo da luminosidade cintilante do "quase céu", cuja "teofania dos signos" (esse acorde divino da criação) Haroldo de Campos (1979, p. 45) aproxima de uma ideia de linguagem poética como "natura naturante". Essa linguagem, que viajara do "quase céu" até uma espécie de "quase hades", pretende ser uma aventura por "partículas / sonoras" sem devaneios metafísicos, sem qualquer ideia de fusão com o universo ou de revelação da clareira do ser. ${ }^{10}$ Sua essência, qual a potência de ser e de existir da enteléquia goetheana, não se separa da própria existência, da física (e não da metafísica) do poema - vale dizer, de seus efeitos rítmicos e realizações vocovisuais:

10 Em outro contexto, ver a esse respeito Costa Lima (2013). 
frases

no papel

arestas de grafite

sub

tendendo

a umbrela

arfante

$[\ldots]$

semência

pó de luz

estelante

grafo

mas: palavras

simples

como este

agora

todavia

aqui

partículas
sonoras
dígitos de
tempo
dúvida
lugar
ad

versáteis

(CAMPOS, 1979, p. 31)

Como se percebe, em Signantia a operação do poema se distingue pela quebra inusitada, tanto das palavras - o que cria efeitos de adensamento pela ambiguidade ("sub/ tendendo"; "ad/ versáteis") - como das linhas o que acrescenta uma performance visual à sua leitura oriunda de cortes e espaçamentos inusuais e de uma não coincidência entre unidades rítmicas e sintáticas. Nessa quebrada, se destaca uma festa dos signos que usa a espessura da página em um desempenho verbal e visual de produtiva mobilidade e multiplicidade de sentidos. Não seria esta uma curiosa utopia de Signantia: uma viagem pela desordem produtiva de palavras ad/ versáteis? E não seria essa viagem uma espécie de "utopia do poema” - para dizer com Henri Meschonnic (2002, pp. 179-183), ainda que em outro contexto -, que faria do ritmo (visual e verbal) uma forma de reinterrogação do próprio sentido do signo? Cabe ainda acrescentar: tal 
"signância" não poderia ser lida como uma reencenação do ato primeiro do próprio imaginário utópico, qual seja, a criação nem tanto de uma "ilha da utopia", mas de uma linguagem sobre a ilha da utopia, ou seja, de um logos utópico? E esse logos sem-lugar (ou topos) não faz da própria espessura da página o espaço para interpelar não um tempo futuro, mas "este/ agora/ todavia/ aqui/ [...]/ dígitos de/ tempo/ dúvida/ lugar/ ad/ versáteis”?

O poema e a utopia, o poema como utopia: em ensaio de 1984 ("Poesia e modernidade”, republicado como capítulo final de $O$ arco íris-branco, em 1997), Haroldo de Campos sugere a possibilidade dessa convergência na medida em que uma atitude de vanguarda e uma consciência histórica também convergiam para projetos coletivos - estéticos e políticos - rumo ao futuro. Signantia ainda é escrito sob o pathos da vanguarda concretista. Porém, ao insinuar um intenso aqui e agora, sem a perspectiva redentora de um futuro ideal, não parece corresponder inteiramente a essa descrição retrospectiva sobre o pathos vanguardista. Quando pouco, o livro permite nuançar a clara dicotomia do ensaio de 1984 entre um antes (o da convergência entre utopia, construção do futuro e projetos coletivos de vanguarda) e um depois (um tempo pós-utópico, porque destituído do antigo pathos "futurista" sob a égide de ações coletivas). Sob o signo da viagem, "este agora todavia aqui" da Signantia sugere um ritmo cuja espessura temporal tem parte com o paradoxo e com o imprevisto, ou melhor, com exigências que deixariam para trás a coincidência entre um logos utópico e um conteúdo indubitável para uma consciência. Nesse sentido, a utopia do poema talvez seja apenas uma "signância", ou melhor, uma viagem dos signos rumo ao intenso agora - uma utopia da agoridade."

"Sob a espécie da viagem" (dos e pelos signos): talvez não seja por acaso que Haroldo de Campos tenha se colocado sob esse ponto de vista em Galaxias, publicado no mesmo ano (1984) em que concluiu "Poesia e modernidade”. De difícil classificação, entre a prosa e a poesia, entre o épico e o epifânico, esse livro se estrutura a partir de um tema recorrente: "a viagem como livro e o livro como viagem (embora - e por isso mesmo não se trate de um 'livro de viagem')" (CAMPOS, 1984, [s.p.]), afirma o autor em texto datado de 1983 e inserido como pós-escrito da primeira edição. Em outro momento, o autor diz que o livro é apenas um "ensaio", como

11 Agoridade é o modo como o poeta traduz e se apropria da noção benjaminiana de "tempo do agora" presente, por exemplo, nas “Teses sobre a História”. Esse procedimento é explicitado na parte final do ensaio "Poesia e modernidade". 
se "ensaiar" pudesse dizer sobre essa aventura pela linguagem. De fato, por intermédio desse longo ensaio, que mais uma vez joga luz ao topos da viagem, o autor compõe cinquenta estações de uma aventura (geográfica, linguística e mítica) polivalente, embora autores diversos como Boitani (2005b, pp. 164-165) e Jackson (2005, pp. 39-42) reconheçam, no narrador, uma sombra específica: a de um Ulisses sem fronteiras, transitando entre o mundo clássico de Homero e Dante e os ritmos multifacetados do mundo contemporâneo (tanto os da vida urbana dos personagens do Ulysses, de Joyce, como os ritmos polissonoros dos "cantos" de Pound).

Comparado a Signantia, Galáxias parece articular de modo expansivo e prolixo um conjunto de elementos que, depois, Finismundo iria mais uma vez retomar de maneira condensada. Veja-se, como exemplo dessa expansão galáctica, o instante em que Haroldo de Campos cita a nékuia de Odisseu e seu encontro com Tirésias. Esse episódio é representado sem qualquer dimensão narrativa. Em um giro caleidoscópico e reiterativo em torno dos nomes e dos epítetos das personagens, a passagem mais se parece com uma odisseia tautológica, ou melhor, "uma tautodisseia":

\footnotetext{
solitudinário odisseu ouninguém nenhúrio ausculta um tirésias de fezes vermicego verminíquo vermicoleando augúrios uma labirintestina oudisseia [...] oudisseu nenhumnome parou aqui este livro uma tautodisseia dizendo-se parou aqui e passou além morto roxo exposto como um delfim
}

Esse trecho foi elaborado, segundo depoimento do autor, em 1973. Inserido no livro em seu 48 ${ }^{\circ}$ canto, a passagem ecoa e desdobra o modo como o herói grego se apresentou ao gigante Polifemo: nomeando-se "Ninguém" - "Ninguém é o meu nome" (HOMERO, 2011, canto IX, pp. 360-370) -, o rei de Ítaca brinca com a língua para levar seu adversário à confusão e à perdição, quando este pede por socorro dizendo que "Ninguém" o havia ferido. Nesse episódio, a hybris (ou a soberba em desafiar e enganar Polifemo) se institui através de uma astúcia da/na linguagem perante um gigante incapaz de reconhecer as ambiguidades e o colorido da linguagem; e a quem, talvez por isso mesmo, só coubesse um recurso, sem matizes, à ameaça e à violência.

Finismundo tem muito das Galáxias. Mas seus versos já seriam de outra natureza. Menos circular ou reiterativo, o poema de 1990 é elaborado em duas partes bem diferentes. Na primeira, como reitera o próprio poeta naquele "depoimento" de 1996, as luzes dos astros orientam o navegante na direção do seu naufrágio; na segunda, as luzes de um mundo urbano e desencantado (semáforos, sirenes, computadores) são lidas ironicamente 
como epitáfios do antigo heroísmo. Por outro lado, "Finismundo" também tem algo de Signantia, livro em que a hybris fora pensada sob o "olho fosfóreo de Dante". Mas no poema de 1990 a curiosidade desmedida do herói é o eixo que estrutura um conjunto de versos que, se ainda abrigam muitos procedimentos apreendidos das experimentações de vanguarda, adquirem agora uma feição mais narrativa, se comparada à linguagem visual e entrecortante do livro de 1979. De todo modo, entre Galáxias e Signantia, bem como entre Homero, Dante e Pound, o velho Haroldo de Campos catalisa dados da sua obra precedente para relançá-los rumo ao "aventuroso deslugar" de uma "última viagem", que cabe, agora, analisar.

6.

No canto 11 da Odisseia, Homero conta que o rei de Ítaca, após naufragar, foi acolhido na ilha dos Feácios. Ali se fez de aedo e recordou, aos seus hóspedes, muitas de suas venturas, entre as quais sua descida ao reino dos mortos e seu encontro com o profeta Tirésias, quando ouviu, dele, o seu destino: encontrar a morte, em idade avançada, ex halos: "ex" ("proveniente do" ou "fora do") "halos" (mar). Profecia ambígua sobre a morte de Odisseu, que, como diria Haroldo de Campos (1998, p. 57) em Finismundo, não conta "o fado demasiado./ Ou se conta/ desvaira variando: infinda o fim”. Piero Boitani (2005a), por sua vez, lembraria que justamente essa ambiguidade teria aberto para os futuros leitores e intérpretes do episódio as mais diversas versões e continuações, fazendo dessa lenda, fonte infinita de reelaborações. Desde a Antiguidade, foram várias as intepretações sobre a profecia "que os leitores de épocas posteriores - continua Boitani -, sejam eles poetas ou intérpretes, tentam preencher por meio de novas histórias" (p. 7).

Eis, por exemplo, lembra o autor, o gramático latino Caio Júlio Solino fazendo de Odisseu o fundador de uma cidade no estuário do Tejo, Ulixabona, mais tarde reconhecida como Lisboa - "Este que aqui aportou/ Foi por não ser existindo/ Sem existir nos bastou/ Por não ter vindo foi findo/ E nos criou", podemos acrescentar com os versos de Mensagem, de Fernando Pessoa ([s.d.], p. 2) -. Outros, porém, o fizeram morrer no mar em uma viagem rumo ao desconhecido, lenda esta recriada, como já mostrado neste texto, por Dante. Por sua vez, tradutores modernos da Odisseia também variaram o sentido da profecia de Tirésias. Na década de 1860 , por exemplo, a primeira versão brasileira integral de Homero, feita por Odorico Mendes (HOMERO, 200o), interpreta a profecia com os olhos, talvez, de Dante: “Ali do mar, vir-te-á mais lenta a morte,/ Feliz 
velho, entre gentes venturosas./ Preenchidos serão meus vaticínios" (canto XI, versos 103-105, grifos nossos). Já na década de 1940, a segunda tradução brasileira integral, feita Carlos Alberto Nunes (HOMERO, 2011), relê as palavras de Tirésias em sinal trocado "Distante do mar há de a Morte/ te surpreender por maneira mui doce e suave, ao te vires enfraquecido em velhice opulenta" (canto XI, versos 134-136, grifos nossos).

Pois, se variam as reverberações da profecia de Tirésias, Finismundo também deseja participar dessa múltipla leitura. E assim o faz em meio a uma atmosfera mítica, notadamente na primeira de suas duas partes, embora Carlito Azevedo tenha notado, numa ótima resenha publicada na Folha de São Paulo em 1997, que a variação dos tempos verbais do poema é capaz de trazer essa atmosfera para mínimas distâncias do seu leitor:

\begin{abstract}
Haroldo nos conta, em seu depoimento, que dividiu o poema em dois tempos. Um tempo passado, quando Odisseu resolve empreender mais uma viagem, e um tempo presente, quando um Ulisses mais joyceano que homérico perambula pelas ruas cotidianas [...]. Mas essa articulação em dois tempos, explicitada no poema por meio dos números um e dois, esconde outra articulação ainda temporal, mas muito mais sutil: a alternância de tempos verbais na narração de fatos passados [...]. Essa mistura vai se dar no Finismundo, de forma crescente. Até o verso 67 do poema, a história de Odisseu é narrada no presente: Odisseu "re-propõe a viagem", "Pre-medita transpassar o passo" [...]. Até que, no verso 68, a narrativa começa a se desenrolar no passado: "Ele foi/ [...] Odisseu foi. Perdeu os companheiros". A partir daí os tempos verbais começam a se alternar quase verso a verso [...] Esse tensionamento do poema longo, narrativo, por meio da alternância de tempos verbais mais característicos da épica e da lírica, além de preparar o salto no tempo a ser dado na parte dois do poema, em que se narram fatos presentes e se opera uma brutal dessacralização da linguagem [...] objetiva o tempo virtual do poema. ${ }^{12}$
\end{abstract}

12 A resenha de Carlito Azevedo, intitulada "A integridade da poesia", veio à luz em 1997 a propósito de Sobre Finismundo, aquela reedição de 1996 do poema acompanhada de depoimento do autor sobre sua gênese. Essa resenha acolhe, em parte, a leitura feita por outro poeta-crítico, Sebastião Uchôa Leite, a propósito da primeira edição do poema (1990), publicada no Jornal do Brasil ("Entre as sereias e as sirenes", disponível no site da Biblioteca Nacional). O texto de Sebastião Uchôa, aliás, é citado pelo próprio Haroldo de Campos no depoimento de 1996 como referência para pensar o modo de articulação dos momentos épico e prosaico, homérico e joyceano das duas partes do poema. Ainda que subscreva a observação Uchôa-haroldiana, o texto de Azevedo, como visto, privilegia a sutil articulação dos tempos verbais como modo de entender a espessura temporal do poema. A essas duas resenhas (Uchôa Leite e Azevedo) vêm se somar tanto um ensaio de Nelson Ascher (2009) como outro de Marcos Siscar (2016) no quadríptico de poetas-críticos que ajudaram a definir os parâmetros do que se leu e do que ainda se lerá neste artigo. Esse quadro teve uma única e importante intromissão: a de Piero Boitani (2005) em "A última viagem de Ulisses no Brasil", o primeiro intérprete, salvo engano, a sugerir uma atmosfera utópica em Finismundo. Exceção feita a Uchôa Leite, os textos de Ascher, Siscar e Boitani ainda entrarão, em momento oportuno, neste texto. 
Assim, em meio à alternância dos tempos verbais da parte 1, o mito se faz presente quando um último Odisseu "re-/ propõe a viagem". Em Finismundo, então, ficamos sabendo que o rei de Ítaca, já senescente, abandona seu lar e sua esposa Penélope para, com antigos companheiros, se lançar mais uma vez numa aventurosa navegação. Com certo decoro épico, Haroldo de Campos opta por uma dicção elevada para dar conta dessa iniciativa, tensionada até o verso 67 (pode-se reforçar a observação de Carlito Azevedo - 1997), por verbos no infinitivo - "passar" (avante), "transgredir" (as medidas), "ousar" (o mais), "reincidir" (na partida), "partir" (o lacre), "desvirginar" (o véu) -, infinitivo que, dando conta do caráter do herói e de suas iniciativas, desaparece do poema a partir do verso 68. Desde de então, a viagem ("Ele foi..."), e não apenas uma ideia do "viajar", como sugeriu Nelson Ascher (2009, p. 282), começa a ser efetivamente narrada com suas alternâncias entre passado e presente ("Odisseu foi/ [...] Odisseu não aporta”).

Nesse contexto, Haroldo de Campos explora o sentido da viagem num sutil jogo pela "física do poema", ou seja, pela experimentação de efeitos rítmicos e realizações vocovisuais aprendidas na fase heroica do concretismo e também exploradas em Signantia. Veja-se, por exemplo, o uso de parênteses no andamento inicial do poema, recurso este que mimetizaria uma pausa meditativa do próprio viajante; ou então a quebra das palavras na mudança das linhas, com a qual se criam ambiguidades ou duplo sentido na descrição do sentido da viagem. Esses efeitos estão presentes na bela passagem que se transcreve abaixo, na qual o velho Odisseu, cabeça branca, é representado num "impasse a ser" ("enigma” ou "enigma resolto"?), a partir de uma rítmica verbo-visual marcada pelo desmembramento das palavras, cujas partes se espalham por diferentes linhas e criam novas combinações de sentido. Nessa passagem, o poeta trata, pois, de ritmar o próprio impasse meditativo do viajante antes de sua deliberação final:

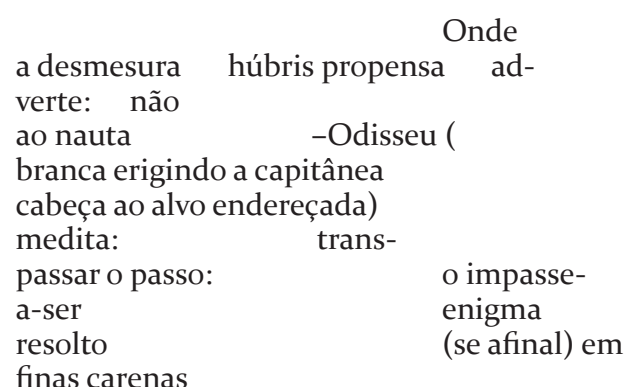

finas carenas

de ensafirado desdém 
Nesse contexto, o poeta retoma, sobretudo, um temário central de Signantia: a hybris ("húbris propensa" e, alguns versos adiante, "húbris propulsa"), em torno da qual faz gravitar todo o léxico da transgressão e da ousadia: "a desmesura", "tentar o não tentado", “o desatino", a "missão voraginosa”, entre outras palavras e expressões. Desde os primeiros versos do poema sabe-se, de fato, que essa seria uma aventura rumo ao desconhecido. A epígrafe do poema, retirada da Amorosa visione [Amorosa visão] de Bocaccio e mantida em italiano - per voler vedere trapassò il segno [por querer ver ultrapassou o sinal] -, já prenuncia os primeiros acontecimentos do poema: um herói navegante ultrapassando, no mar Mediterrâneo, as colunas de Hércules, aquelas que, no estreito de Gibraltar, entre a África e a Ibéria, delimitavam, desde a antiguidade, as fronteiras entre o já visto e o apenas imaginado. Mas ultrapassar as fronteiras em atos de ousadia também fora imaginado na antiguidade, a exemplo do coro da Medeia de Sêneca (2014, ato II, linhas 375-379). Trata-se de passagem retomada na época de Dante e também nos tempos de Cristóvão Colombo, a evocar séculos vindouros "nos quais o Oceano romperá os vínculos e a esfera terrestre estará aberta, nos quais a deusa do mar Tétis revelará novos mundos e Tule [ilha nas bordas do mundo conhecido] não será o ponto último da Terra" (coro ecoado em chave irônica no urbano Ulisses da segunda parte de Finismundo, que aspira, no máximo, a "penúria de última/ Tule"). ${ }^{13}$

Diante das vigilantes colunas de Hércules, o Odisseu haroldiano medita: "trans/ passar o passo: o impasse-/-a-ser enigma/ resolto (se afinal)..." Após, adentra o desconhecido mar oceânico: "no lugar/ da ventura, o aventuroso/ deslugar", ou melhor, o terreno imaginário que, na esteira do canto XXVI do "Inferno" de Dante, Finismundo descreve como a “proibida/ geografia do Éden - Paradiso/ terreno: o umbráculo interdito”. Odisseu continua. Mas "vendo já/ o alcançável Éden ao quase/ toque da mão: os Deuses conspiram", diz o poeta com um plural ("os Deuses”) mais próximo do Olimpo que do Céu cristão. Então, uma ventania vinda do alto - "o Céu suscita os escarcéus" - faz com que a embarcação sucumba num naufrágio. Após o "Lance/ dos lances [...]/ Água só Rasuras", continua o poeta num léxico que ecoa, agora, o tema do naufrágio em Mallarmé, presente em poemas como "Brinde" [Salut], "Brisa Marinha" [Brise Marine]), "À só tenção de ir além” [Au seul souci de voyager]. Nas

13 Sobre essa passagem do coro de Sêneca, ver os comentários de A. J. Boyle em sua edição crítica (2014, pp. 227-229). 
palavras de Augusto de Campos (2006, p. 28), companheiro de viagem nas traduções da obra do poeta francês, esses poemas

[...] já insinuam a temática posterior do poeta-navegante [do poema "Um lance de dados"/ (Un coup de dés)], desafiando o abismo dos elementos, entre o fácil naufrágio e a fácil sobrevivência, na tentativa quase suicida de lançar os dados do poema entre o acaso e o nada. ${ }^{14}$

A primeira parte do poema opera, pois, um jogo erudito de citações para preencher os vaticínios de Tirésias com uma "morte que provém do mar salino", morte esta que ecoa tanto a versão de Dante para os últimos dias do herói como a da "Odisseia brasileira" de Odorico Mendes (HOMERO, 200o). Esta última obra, de resto, é mais de uma vez homenageada no poema, como no uso de expressões e termos raros ("umbráculo interdito", "escarmentam”), palavras compostas (“doceamargo", "maroceano”), no hipérbato (como na inversão sintática da passagem "onde de Hércules as vigilantes colunas às ondas escarmentam") ou, por fim - como notara Nelson Ascher (2009, pp. 285-286) -, nos decassílabos finais da primeira parte do poema ("Serena agora o canto convulsivo/ o doceamargo pranto das sereias/ ultrassom incaptado a ouvido humano"), que retomam o metro camoniano usado por Odorico em sua tradução de Homero. Por intermédio de uma dicção Odorico-camoniana, Haroldo de Campos parece, mais uma vez, operar num registro próximo ao de The Cantos, especialmente do seu $\mathbf{1}^{\mathbf{0}}$ canto, em que Pound, como visto, reviveu o inglês arcaico e aliterativo do poema medieval Seafarer em sua tradução (para o inglês) da tradução (latina) de Homero. De fato, esses elementos apenas reforçam o fato de que a atmosfera mítica da primeira parte de Finismundo também pode ser lida num registro metapoético, como se o poema fosse emblema, também, de uma viagem criadora e tradutória por diferentes línguas, temporalidades e técnicas poéticas.

Nesse sentido, a descrição da primeira parte do poema como "mitopoético", sugerida atrás, éinsuficiente. Afinal, enquanto o herói mítico

14 Na leitura de Marcos Siscar (2016a, p. 56), "Odisseu é aquele que 'perdeu os companheiros', como diz o poema: numa escala bem menor que a escala dos séculos, o passado concluído poderia soar como uma alusão ao fim do coletivismo de vanguarda; e o recomeço, 'desmemoriado de Ítaca', de uma inquietude que rejeita as glórias prometidas pelo 'regaço de Penélope”'. Assim, em sua primeira parte, o poema já insinuaria uma dimensão metalinguística associada ao diagnóstico haroldiano, elaborado nos anos 1980 em textos como o já citado ensaio sobre "Poesia de modernidade" (de 1984), sobre o fim das vanguardas. Voltaremos ao argumento de Siscar um pouco mais adiante. 
viajava para cumprir um destino, e não para buscar novidades; e enquanto o naufrágio do Ulisses de Dante abrira as portas para o cumprimento de uma inequívoca pena, a primeira parte do poema haroldiano, a despeito da sua atmosfera lendária, já transcorre no tempo da história. Finismundo é um poema com acontecimentos e seu herói é exposto à mudança de planos, a diferentes temporalidades e à impossibilidade de um retorno ao mesmo. ${ }^{15} \mathrm{O}$ que Haroldo de Campos (2002b, pp. 65-66) dissera, em outro contexto, sobre seu poema $A$ máquina do mundo repensada talvez valha para uma variável de caráter histórico animada, em Finismundo, pela curiosidade desmedida, pelo

[...] desejo de, na dúvida, explorar os possíveis que a hermenêutica do enigma oferece: não crendo, nem descrendo, mas duvidando e inquirindo, no sentido de buscar (até onde factível) o conhecimento. A história deve duvidar (no sentido grego de historêo, inquirir, perguntar).

Não deixa de ser extraordinário que o naufrágio, com o Paraíso "ao quase toque da mão", deixe em aberto o sentido da história: no plano dos acontecimentos, o viajante não transforma o "quase-céu" em terra conquistada; no plano da hermenêutica do enigma, não o converte em conteúdo para uma consciência. Em Signantia o poeta já sugeria, em epígrafe retirada de Novalis, que "o paraíso não se pode conhecer, por existir na terra apenas em estado de dispersão” (CAMPOS, 1979, p. 25). Finismundo, por sua vez, faz seu viajante esconjurar os deuses do lar ("o além retorno o após") e a memória como fonte do hábito ("o/ além memória - o/ revés”) para lançá-lo “mais além”. Porém, um novo (êxito ao) revés fez que o herói vislumbrasse um lugar para além do horizonte do "seu" lugar, um tempo para além do horizonte do "seu" tempo. ${ }^{16} \mathrm{De}$ resto, não é justamente a presença do que nunca esteve aí que, tornando

15 Sobre a diferença entre a lenda e a história nos quadros da representação da realidade e da figuração das personagens poéticas, ver o primeiro capítulo do livro Mimesis de Auerbach (1976): "A cicatriz de Ulisses".

16 Em outro contexto, retoma-se aqui a descrição de Lévinas em "La trace de l'autre" (1967) sobre o movimento de evasão para além do horizonte do "meu" lugar ou do "meu" tempo. Nesse texto, Lévinas sugere dois diferentes modelos de viagem: o nostos do Odisseu homérico, com seu retorno ao lar e à condição de senhor, e a viagem sem retorno e sem repouso de Abrahão. O autor não faz menção ao Ulisses de Dante, que talvez combinasse, numa só personagem, traços dos dois modelos. Sobre Lévinas, ver também a leitura de Miguel Abensour (1991) em "Penser l'utopie autrement", especialmente quando o autor demonstra que a evasão levinasiana, a contrapelo da resignação ao mesmo, pode ser lida sob o signo da utopia. 
possível a viagem, pôde ser nomeada, desde o livro fundador de Thomas Morus, como utopia? E não foi a impossibilidade de se resignar ao mesmo que tornara possível, para Haroldo de Campos, visar um tempo ou um lugar que não fosse "seu"?

\section{$7 \cdot$}

Mas o poeta que pensara, no lugar da ventura, "o aventuroso deslugar", termina complicando um pouco mais as coisas na segunda parte do poema. Pois a história continua pela via de um Ulisses urbano e sem fogo prometeico. Sua hybris capitula "num coração cotidiano", como se refizesse o périplo já descrito por Platão, no final da República, em episódio sobre o mito de Er, quando a alma de Ulisses manifesta o desejo de reencarnar num "homem comum": lembrando "dos anteriores trabalhos, quis descansar da ambição, e andou em volta a procurar, durante muito tempo, a vida de um particular tranquilo" (PLATÃO, 1987, X, 620, c-d). O poeta não parece fazer referência ao sedimento platônico da personagem, embora evocasse sua reencarnação na vida prosaica do Ulysses de James Joyce. De fato, na segunda parte do poema, a atmosfera de Finismundo é esvaziada de seu acento sublime. Em contraste com a primeira, acentua-se a paráfrase irônica da antiga grandeza, segundo palavras do poeta (CAMPOS, 1990) já na primeira edição do poema.

Essa perspectiva irônica deve ser levada ao pé da letra, embora problematizando um pouco os passos propostos pelo autor. De fato, se na primeira parte de Finismundo encontra-se um viajante lançado à distância de si mesmo ("além memória" e "além retorno"), a paráfrase irônica da segunda parte enuncia o retorno e a ancoragem do logos viajante numa consciência senhora de si e de sua história. Os primeiros versos dessa segunda parte (indicada no andamento do poema com o número 2) chegam a representar essa ancoragem num momento preciso, quando elimina a própria distância entre o poeta e seu leitor, ambos incorporados à cena desencantada que ali começa a se desenhar:

17 Segundo Piero Boitani (2005, p. 162), em "A última viagem de Ulisses no Brasil", Finismundo descreveria uma viagem "não rumo a um lugar, mas rumo a um outopos, uma utopia, um aventuroso 'deslugar'. Para um locus contradictionis: terrestre e/mas paraíso, ‘umbráculo' e/mas 'lucarna”'. 
2.

Urbano Ulisses

sobrevivido ao mito

(eu e Você meu hipo-

côndrico crítico

leitor).

(CAMPOAS, 1996, pp. 58-59)

A encenação de um "eu e Você" - semelhantes, ambos, ao "Urbano Ulisses", embora apenas ao "Você" seja reservado o epíteto de "hipo/ côndrico crítico" - faz adentrar no poema uma espécie de "eu" já presente em outros momentos da poesia haroldiana, especialmente quando faz dos versos desafio lançado a uma crítica avessa à poesia concreta ou aos poetas oriundos do concretismo. O livro A educação dos cinco sentidos (CAMPOS, 1985), por exemplo, publicado cinco anos antes de Finismundo - e no mesmo ano do ácido debate entre Augusto de Campos e Roberto Shwartz a respeito da publicação do poema "pós-tudo" -, enfim, esse livro publicado em 1985 se inicia com dois poemas que são bons exemplos desse traço agonístico do "eu" lírico. Veja-se, por exemplo, o segundo desses poemas, a "Ode (explícita) em defesa da poesia no dia de São Lukács", quando o autor compara certa crítica aos antigos membros do aparelho burocrático soviético (os apparátchiki): "os apparátchiki te destestam/ poesia/ porque tua propriedade é a forma” (CAMPOS, 1985, p. 17).

Alguns anos depois, nos versos de "Dialética", inseridos naquele mesmo livro que republicou Finismundo (Crisantempo, de 1998), a crítica se explicita: "O/ crítico/ sociologóide/ dono e/ tutor da verdade/ perguntou-se/ (a sério)// o que seria do/ poema 'pós-tudo'/ [...] num/ país socialista?" (CAMPOS, 1998, p. 156). Tributário de certo "demônio da negação" de matriz simbolista, como notara, em outro contexto, Leda Tenório da Motta (2005, pp. 329-342), bem como de uma sátira gregóriooswaldiana, esse me parece um aspecto menos interessante da poesia haroldiana, especialmente quando a ousadia experimental se acomoda mal à intromissão de um eu superior.

Mas, em Finismundo, essa intromissão é contida pelo papel que agora cumpre: o de acentuar a própria passagem da diç̧ão elevada da primeira parte do poema para um tom dessacralizado, para retomar as palavras de Carlito Azevedo (1997, [s.p.]). Ou talvez se pudesse dizer que os primeiros versos da segunda parte do poema descrevem o que parecia improvável ao longo de sua primeira parte: aquele que se lançara para fora de si mesmo ensaia, agora, um movimento de retorno a si, à consciência de si, 
explicitamente representada como uma autoconsciência crítica e reflexiva. Tudo se passa como se o "além-memória" e o "além-retorno" retornasse, agora, à Ítaca natal da poesia moderna, ou melhor, à autoconsciência irônica vinda do romantismo alemão, que opera no poema fazendo com que a aventura humana e a busca pelo conhecimento sejam explicitadas como um jogo poético entre "eu e você". Trata-se, porém, de uma ironia que se distingue do espírito da vingança punitiva dos versos já citados de A educação dos cinco sentidos. Em Finismundo, ela trabalha para colocar em coexistência os contrários ("eu e você", mas também o "Odisseu" da parte 1 com o "Ulisses" da parte 2), ao mesmo tempo em que explicita que a crise do antigo heroísmo e a crítica à vida contemporânea seriam feitas do ponto de vista de uma consciência poeticamente reflexiva.

Nesse sentido bastante específico, essa Ítaca natal da poesia moderna não seria uma ironia derivada dos "Fragmentos críticos" de 1797, de Schlegel, que assentariam seu espírito, resume Sébastien Rongier (2007, pp. 47-54), na refutação da ilusão mimética, na subversão de normas e convenções, na coexistência criativa dos contrários e numa consciência clara de seu paradoxo fundamental: revogar criticamente o mundo de modo a reconstruir o que não iria bem? Em Haroldo de Campos, esse espírito alimentara sua libertação de certa tradição romântica mais afeita à cor local. Ao mesmo tempo, ele permitira (segundo termos de ensaio de 1984, "Poesia e modernidade") novo impulso em favor da poesia, e não em favor - como sugeria A teoria do romance luckaciana - de "uma nova épica de 'base prosística, o romance', 'a moderna epopeia burguesa”' (CAMPOS, 1997, p. 256). Mas Haroldo de Campos não ficara por aqui. Talvez um espírito irônico também estivesse presente naquilo que Siscar (2016a) identifica como um paradoxo constitutivo da obra haroldiana desde esse ensaio de 1984: diagnosticar o fim das vanguardas e de projetos de futuro e, ao mesmo tempo, projetar as linhas mestras de uma nova arte poética, de uma nova "poesia da agoridade" feita de sínteses provisórias. Não seria por isso que o ensaio "Poesia e modernidade", como sugere Siscar (2016a, p. 44), se constitui como uma espécie enviesada de manifesto, a ponto de o autor nomear sua própria obra subsequente ( $A$ educação dos cinco sentidos) como uma poesia da agoridade ou "pós-utópica"?

Finismundo, por sua vez, manifesta uma particular fatura irônica. Como visto, o viajante da primeira parte do poema é, na segunda, ironicamente explicitado como um poeta a compartilhar do mesmodestino urbano e cotidiano de seu hipocôndrico crítico-leitor. O "eu” que tematiza 
esse destino comum não deixa de ancorar sua observação na consciência de sua própria diferença, embora essa diferença, antes de se desenvolver pelos desdobramentos de um "eu superior", seja a mola propulsora do jogo de contrários do poema. Ademais, esse jogo ainda ganha amplitude com a introdução de uma linguagem trivializada em meio ao léxico raro, por intermédio da qual a sublime luminosidade dos astros, que antes guiara o herói em suas aventuras pelo desconhecido, é ofuscada pelas "ninharia[s] flamífera[s]" da moderna vida urbana:

Não há. Vigiam-te os semáforos.

Périplo?

Teu fogo prometeico se resume

à cabeça de um fósforo. - Lúcifer

portátil e/ou

ninharia flamírera.

(cabeça fria)

Capitula

tua húbris.

(CAMPOS, 1996, p. 59)

E aqui a hybris faz sua derradeira entrada no poema apenas para dar conta de um mundo prosaico e abandonado pelos deuses, próximo da reencarnação moderna do Ulisses platônico, qual seja, o urbano Ulisses de Joyce, sem esperanças a realizar (ao menos como um dia esperou o Ulisses de Dante) e sem histórias memoráveis para contar (como um dia contou, qual um aedo, o Odisseu homérico na corte dos feácios). Nesse sentido, Finismundo parece se encerrar perguntando sobre as possibilidades de um "aventuroso deslugar" num mundo destituído de aventuras. Porém, sua última ironia talvez seja esta: repensar a banalidade cotidiana em meio a uma hermenêutica poética intensificada pela multiplicação dos pontos de vista sobre o seu sentido final, multiplicação esta provocada pelos tantos recursos que o poeta mobiliza ao longo do poema: seja em sua técnica de citação, mesclando diferentes épocas e espaços numa mesma história; seja no elaborado contraste entre um antigo Odisseu e um moderno Ulisses, por intermédio dos quais uma atmosfera mítica e outra histórica se entremesclam; seja no articulado manejo de diferentes tempos verbais, com os quais o poeta cria efeitos alternados de aproximação e distanciamento dos feitos narrados; seja ainda nas ambiguidades e intensificações de sentidos provocadas por uma sintaxe quebrada, por uma rítmica dissoluta e pelo uso de vocábulos muitas vezes raros e inusuais. 
De resto, em meio ao naufrágio final, a ironia "infinda o fim". Como já lembrava Nelson Ascher (2009), o poema parece propor "dois finais" (relativos às suas duas partes) depois dos quais nada mais haveria. Entretanto, revela que se vai além, "numa viagem que vem depois da última. O título, assim, é menos uma definição do conteúdo do poema que um marco a ser superado, um desafio que convoca o poeta à húbris" (p. 284). É certo que, após os fins, se está longe tanto do heroísmo antigo como das modernas explorações rumo à "distância absoluta" das utopias. Mas talvez se esteja próximo do que Haroldo de Campos imaginou, no ensaio de 1984, como um "princípio-realidade" ancorado no presente e na crítica aos paraísos sistemáticos. Esse princípio, dizia o autor, só conheceria sínteses provisórias, "e o único resíduo utópico que nele pode e deve permanecer é a dimensão crítica e dialógica que inere à utopia” (CAMPOS, 1997, p. 269). Ao fim e ao cabo, não seria a hybris irônica de Finismundo o logos utópico que sobrevive ao naufrágio, o resíduo crítico com o qual buscara não capitular?

\section{ITHACA REVERSED}

Abstract: This paper intends to review the poem "Finismundo: the last voyage", published by Haroldo de Campos in 1990. The aim of the analysis is to demonstrate how the poem develops the theme of Odysseus's voyages with poetic images from various origins, both of the literary canon (especially Homer, Dante and Pound) and of the others books by Haroldo de Campos (that made this theme a central topos of his poetics). This text works with the hypotheses that "Finismundo", although written from a point of view of the sinking of utopias, suggests an ironically utopian hubris.

Keywords: Haroldo de Campos; Odysseus; Utopia.

\section{REFERÊNCIAS}

ABENSOUR, Miguel. O novo espírito utópico. Campinas: Ed. Unicamp, 1990.

ABENSOUR, Miguel. Penser l' utopie autrement. In: ABENSOUR, Miguel; CHALIER, Catherine (orgs.). Emmanuel Lévinas. Paris: Éditions de L'Herne, 1991.

ASCHER, Nelson. O afã de ir além de... In: BEHAR, Lisa Block de (org.). Haroldo de Campos, don de poesía: ensayos críticos sobre su obra. Montevideo: Librería Linardi y Risso, 2009, pp. 25-43.

AUERBACH, Erich. A cicatriz de Ulisses. In: Mimesis: a representação da realidade na literatura ocidental. 2. ed. São Paulo: Perspectiva, 1976. 
AVALLE, D’Arco Silvio. L'ultimo viaggio d'Ulisse. In: Modelli semiologici nella Commedia di Dante. Milão: Bompiani, 1975, pp. 37-63.

AZEVEDO, Carlito. A integridade da poesia. Folha de São Paulo (Caderno Mais), São Paulo, 20/04/1997. Disponível em: <http://www1.folha.uol.com.br/fsp/mais/ fs200415.htm>. Acesso em: 2 abril 2018.

BARBOSA, João Alexandre. Um cosmonauta do significante: navegar é preciso. In: CAMPOS, Haroldo de. Signantia quasi coelum, signância quase céu. São Paulo: Perspectiva, 1979, pp. 11-24.

BENJAMIN, Walter. O narrador: considerações sobre a obra de Nikolai Leskov. In: Obras escolhidas I: magia e técnica, arte e política. São Paulo: Brasiliense, 1987, pp. 197-221.

BOITANI, Piero. A sombra de Ulisses (com caderno de poemas transcriados por Haroldo de Campos). São Paulo: Perspectiva, 2005a.

BOITANI, Piero. A última viagem de Ulisses no Brasil. In: A sombra de Ulisses (com caderno de poemas transcriados por Haroldo de Campos). São Paulo: Perspectiva, 2005b, pp. 157-167.

CAMPOS, Augusto de. Pound Made (New) in Brazil. In: À margem da margem. São Paulo: Cia das Letras, 1989, pp. 99-112.

CAMPOS, Haroldo de. Signantia quasi coelum, signância quase céu. São Paulo: Perspectiva, 1979.

CAMPOS, Haroldo de. Galáxias. São Paulo: Ex-Libris, 1984.

CAMPOS, Haroldo de. A educação dos cinco sentidos. São Paulo: Brasiliense, 1985.

CAMPOS, Haroldo de. De la poesia concreta a Galáxias y Finismundo. 40 años de actividad poética em Brasil. In: Vuelta. Revista mensal, a. XV, n. 177, ago. e 1991, pp. 7-14.

CAMPOS, Haroldo de. Sobre Finismundo: a última viagem. Rio de Janeiro: Sette Letras, 1996.

CAMPOS, Haroldo de. Poesia e modernidade: da morte da arte à constelação. O poema pós-utópico. In: O arco íris branco. Rio de Janeiro: Imago, 1997[1984], pp. 243-269.

CAMPOS, Haroldo de. Da poesia concreta a Galáxias e Finismundo. In: Depoimentos de oficina. São Paulo: Unimarco, 2002a, pp. 37-50.

CAMPOS, Haroldo de. De uma cosmopoesia: sobre $A$ máquina do mundo repensada. In: Depoimentos de oficina. São Paulo: Unimarco, 2002b, pp. 51-59.

CAMPOS, Haroldo de. Crisantempo: no espaço curvo nasce um. São Paulo: Perspectiva, 2004[1998]. 
CAMPOS, Haroldo de. Deus e o Diabo no Fausto de Goethe. São Paulo: Perspectiva, 2008[1981].

CAMPOS, Haroldo de. Entremilênios. São Paulo: Perspectiva, 2009.

CAMPOS, Haroldo de. Ezra Pound: I punti luminosi. In: O segundo arco-íris branco. São Paulo: Iluminuras, 2010, pp. 191-199.

CAMPOS, Haroldo de; CAMPOS, Augusto de. Sousândrade, o terremoto clandestino. In: Re-visão de Sousândrade. 3. edição. São Paulo: Perspectiva, 2002[1964], p. 123.

CAMPOS, Augusto de; CAMPOS, Haroldo de; PIGNATARI, Décio. Mallarmé. 3. edição. São Paulo: Perspectiva, 2006.

FOURIER, Charles. Ouvres complétes: Théorie des quatre mouvements et des destinées génerales. T. 1. Paris: Éditions Antrophos, 1846. Disponível em: <http://gallica.bnf. fr/ark:/12148/bpt6k54805/fi.item.r=ecart>. Acesso em: 2 abr. 2018.

GINZBURG, C. O velho e o novo mundo vistos de Utopia. In: Nenhuma ilha é uma ilha. São Paulo: Cia das Letras, 2004, pp. 17-42.

JACKSON, K. David. Viajando pelas Galáxias: guia e notas de orientação. In: MOTTA, Leda Tenório da (org.). Céu acima: um tombeau de Haroldo de Campos. São Paulo: Ed. Perspectiva, 2005, pp. 39-53.

KENNER, Hugh. The Cantos - 1. In: The Pound Era. Los Angeles: University of California Press, 1971, pp. 9-43.

LEITE, Sebastião Uchôa. Entre as sereias e as sirenes. Jornal do Brasil (Caderno de Ideias), Rio de Janeiro, 6/10/199o. Disponível em: <http://memoria.bn.br/DocReader/ DocReader.aspx?bib=030015_11>. Acesso em: 2 abr. 2018, p. 12-14. LEVINAS, Emmanuel. La trace de l'autre. In: En découvrant l' existence avec Husserl et Heidegger. Paris: Vrin, 1967, p. 121-142.

LEVINAS, Emmanuel. Entre nós. Petrópolis: Vozes, 2005.

LIMA, Luiz Costa. A ficção e o poema. São Paulo: Cia das Letras, 2012.

MATOS, Olgária. Babel e Pentecostes: heterofilia e hospitalidade. In: MOTTA, Leda Tenório da (org.). Céu acima: um tombeau de Haroldo de Campos. São Paulo: Ed. Perspectiva, 2005.

MESCHONNIC, Henri. Le poème comme utopie. In: RIOT-SARCET, Michèle (org.). Dictionnaire des utopies. Paris: Larousse, 2002, pp. 189-193.

HOMERO. Odisseia. 2. edição. Trad. Odorico Mendes. São Paulo: Edusp, 2000.

HOMERO. Odisseia. Trad. Carlos Alberto Nunes. São Paulo: Hedra, 2011. 
Remate de Males, Campinas-SP, v.38, n.2, pp. 853-884, jul./dez. 2018 - 883

MOTTA, Leda Tenório da. Haroldo francês. In: MOTTA (org.). Céu acima: para um tombeau de Haroldo de Campos. São Paulo: Perspectiva, 2005, pp. 15-39o.

PERLOFF, Marjorie. Aumentando a temperatura referencial: reverberações poundianas na poesia concreta brasileira. In: Circuladô: Revista de Estética e Literatura do Centro de Referência Haroldo de Campos, a. V, n. 7, dez. 2017, pp. 27-43. Disponível em: <http://www.casadasrosas.org.br/crhc/arquivos/cr_circulado_7.pdf>. Acesso em: 2 abr. 2018.

PESSOA, Fernando. Mensagem. [s.d.] Disponível em: <http://www.dominiopublico.gov. br/pesquisa/DetalheObraForm.do?select_action=\&co_obra=15726>. Acesso em: 2 abr. 2018.

PLATÃO. República. 5. ed. Lisboa: Calouste Gulbenkian, 1987.

PRÉVOST, A. L'utopie de Thomas Morus: présentation, texte original, apparat critique, exégèse, traduction et notes. Paris: Mame, 1978.

POUND, Ezra. ABC of reading. Londres: Faber and Faber, 1961.

POUND, Ezra. The Translations of Ezra Pound. Londres: Faber and Faber, 1970.

POUND, Ezra. Ezra Pound, poesia. Org., introdução e notas de Augusto de Campos. São Paulo: Hucitec, 1983.

READ, Forrest. Ezra Pound et James Joyce: les odysséans. Les Cahier de L'Herne: Ezra Pound, 1966, [s.p.].

RODRIGUES, Henrique Estrada. Poesia bíblica e utopia em Haroldo de Campos. In: O eixo e a roda: revista de literatura brasileira, Belo Horizonte, v. 24, n. 1, 2015, pp. 42-62. Disponível em: <http://www.periodicos.letras.ufmg.br/index.php/o_eixo_ea_roda/ article/viewFile/7917/8431>.

RODRIGUES, Henrique Estrada. A utopia do mínimo que resta: o lance dos lances do velho Haroldo. In: Viso: revista de estética aplicada, Rio de Janeiro, n. 21, 2017, pp. 25-41. Disponível em: <http://revistaviso.com.br/pdf/Viso_21_HenriqueEstrada.pdf>.

RONGIER, Sébastien. De l'ironie: enjeux critiques pour la modernité. Paris: Klincksieck, 2007.

SENECA. Medea. Introdução, tradução e comentários de A. J. Boyle. Oxford: Oxford University Press, 2014.

SISCAR, Marcos. A alavanca da crise: a poesia "pós-utópica” de Haroldo de Campos. In: De volta ao fim: o "fim das vanguardas" como questão da poesia contemporânea. Rio de Janeiro: 7 Letras, 2016a, pp. 42-66. 
Îtaca ao revés - 884

SISCAR, Marcos. O tombeau das vanguardas: a "pluralização das poéticas possíveis" como paradigma crítico contemporâneo. In: De volta ao fim: o "fim das vanguardas" como questão da poesia contemporânea. Rio de Janeiro: 7 Letras, 2016b, pp. 19-41.

VILLA, Dirceu. Paideuma, ou: como montar seu ideograma poundiano caseiro. In: DICK, André (org.). Paideuma. São Paulo: Risco Editorial, 2010, pp. 37-71. 